\title{
Shift in migration phenology of a wintering population of Dippers Cinclus cinclus in northern Sweden
}

\author{
Förändring i fenologi hos övervintrande strömstarar Cinclus cinclus i norra Sverige
}

\author{
FRANK JOHANSSON, THOMAS BRODIN, DARIUS STRACEVICIUS \& \\ EMIL FÜRSTENBERG-HÄGG
}

\begin{abstract}
Many organisms have been found to respond to global warming by adjusting one or several aspects of their ecology, such as timing of migration events, time at reproduction and size at maturity. We examined changes in arrival and departure times, and age and sex ratios of overwintering White-throated Dippers Cinclus cinclus in northern Sweden, by comparing data collected in 19751979 to a similar dataset from 2010-2014. Between these periods, the average winter temperature had increased by about $2^{\circ} \mathrm{C}$. During the latter period the Dippers arrived in their winter area two weeks earlier and departed three weeks earlier. We found no change in age and sex ratios during the study period.

Frank Johansson, Department of Ecology and Genetics, Uppsala University, SE-751 05 Uppsala, Sweden. Email: frank.johansson@edu.uu.se

Thomas Brodin, Department of Ecology and Environmental Sciences, Umeå University, SE-901 87 Umeå, Sweden.

Darius Stracevicius, Department of Ecology and Environmental Sciences, Umeå University, SE-901 87 Umeå, Sweden.

Emil Fürstenberg-Hägg, Department of Ecology and Genetics, Uppsala University, SE-751 05 Uppsala, Sweden.
\end{abstract}

Received 8 December 2016, Accepted 5 July 2017, Editor: Åke Lindström

\section{Introduction}

Among birds, several effects of climate change have been reported. There are good evidence showing an earlier arrival to, and an earlier departure from the breeding grounds, and these changes are associated with a warmer climate (Hüppop \& Hüppop 2003, Cotton 2003, Møller et al. 2011). However, these changes are not consistent among species groups. For example, Jenni \& Kéry (2003) found that autumn migration had advanced in species overwintering south of the Sahara while those overwintering north of the Sahara had delayed their departure. The result of these studies also suggests that many birds leave from and arrive to their winter areas earlier. Some support for this has been found. For example, Gordo et al. (2005) found that the climate at the wintering grounds had a stronger influence on the arrival date to the breeding area than the climate changes at the breeding areas. However, Thorup et al. (2007) and Van Buskirk et al. 2009 found that autumn migration showed no strong and consistent pattern with regard to departure time from breeding grounds. More data on the arrival and departure time from wintering grounds would therefore be a valuable contribution for a better understanding of the yeararound migration phenology. In addition, there are only few studies available that have focused on how migration pattern changes in birds overwintering in areas where winter temperature goes below $0^{\circ} \mathrm{C}$ for shorter or longer periods. But studies on waterbirds have shown that in these areas ducks have advanced their spring arrival, and winter population densities and species number of waterbirds have increased, since the 1990s (Guilleman et al. 2013, Musilova et al. 2015).

The White-throated Dipper Cinclus cinclus is an interesting species for studying the possible effects of global warming at wintering grounds because it overwinters in areas with low temperature and its wintering areas are well known (Fransson \& HallKarlsson 2008). The Dippers in our study belong to the subspecies C. c. cinclus and breed primarily in western Scandinavia. After breeding, the birds of this sub-species usually migrate $400-750 \mathrm{~km}$ southwest, south or southeast to their wintering areas (Andersson \& Wester 1976, Lehikoinen \& Hakala 1988, Vuorinen \& Tyrberg 1994, Fransson \& Hall-Karlsson 2008). In the wintering areas in northern Sweden, 
the average winter temperature (December-February) has increased with $2-3^{\circ} \mathrm{C}$ from $1961-1990$ to 1991-2011 (SMHI 2015a). This increase in temperature might have affected arrival and departure date of overwintering Dippers in the area.

Lundberg et al. (1981) studied the winter ecology of White-throated Dippers in the province of Västerbotten in northern Sweden, collecting data from 1975-1979 on the arrival and departure time, and age and sex ratios of overwintering birds. By conducting a similar study, our main objective was to determine if migration phenology of Dippers in northern Sweden has changed during the last 35 years, in parallel to the increase in average winter temperature. In addition, we compared the age and sex ratios during this period. Lundberg et al. (1981) found a tendency for females and juveniles to arrive relatively earlier in the autumn, and it is interesting to examine if this pattern has changed. We predict that birds would both arrive at and leave their wintering areas earlier because this would match the earlier arrival and departure to breeding grounds that have been found in several other species (Cotton 2003,
Jonzén et al. 2006). We had no a priori predictions for changes in age and sex ratio.

\section{Methods}

Lundberg et al. (1981) studied the winter ecology of Dippers in three streams in the province of Västerbotten: Ängerån (6334'47’'N, 1950'9'E), Kvarnfors $\left(63^{\circ} 58^{\prime} 13^{\prime \prime} \mathrm{N}, 20^{\circ} 7^{\prime} 8^{\prime \prime} \mathrm{E}\right)$, Norsån $\left(64^{\circ} 15^{\prime} 29^{\prime \prime} \mathrm{N}\right.$, $\left.20^{\circ} 14^{\prime} 48^{\prime \prime} \mathrm{E}\right)$, (Figure 1). For comparison with the results reported in the 1970s, we conducted a similar study in 2010-2014.

Lundberg et al. (1981) visited each location two to three times per month from November to April 1975-1979. During visits, mist nets were used to capture birds, and sex and age were determined according to Andersson \& Wester (1972) and Svensson (1975). Wing length was determined with the maximum length method (Svensson 1975), and individuals with a wing length $>94 \mathrm{~mm}$ were scored as males and those $<94 \mathrm{~mm}$ as females (Svensson 1975). Each bird was also banded with a metal band. Visits once a week during October and May revealed that no Dip-

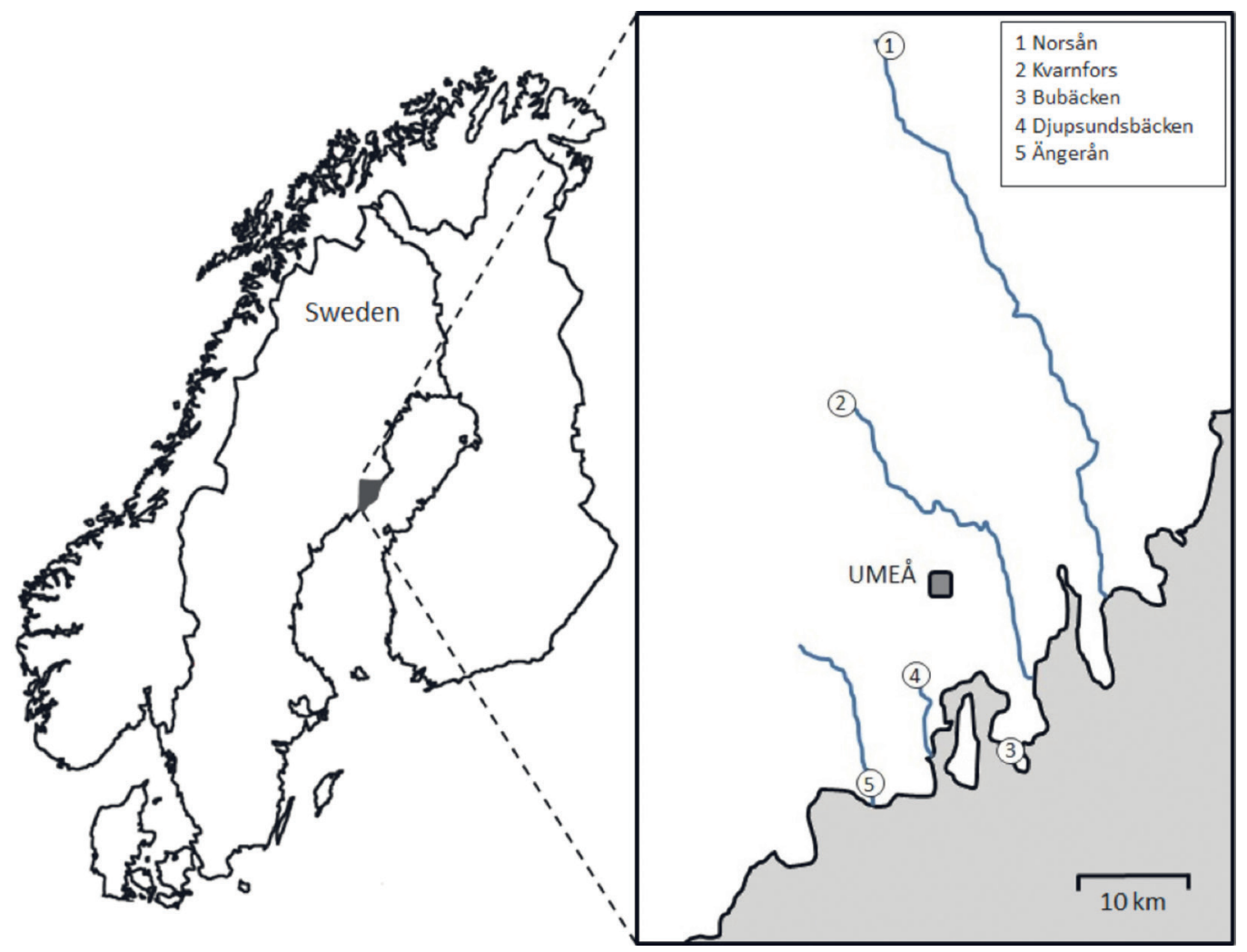

Figure 1. Map showing the study area and localities studied. Karta över studieområdet som visar undersökningslokalerna. 
pers were present in the area during these months. The absence of birds was determined by walking along the streams at a stretch about 400-500 m. All results presented in Lundberg et al. (1981), were based on the number of birds caught and identified through mistnet captures.

In our repeated study in 2010-2014, it was unfortunately not possible to study Dippers at all of the same locations, because of limiting access at the old sites. But one of the sites was the same as in Lundberg et al. (1981). However, all locations are in the same area in northern Sweden and within a radius of $39 \mathrm{~km}$. The locations in our study sites were Djupsundsbäcken (6341'30'N, 20²3'13”E),

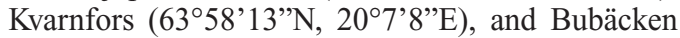
$\left(63^{\circ} 45^{\prime} 19^{\prime \prime} \mathrm{N}, 2^{\circ} 12^{\prime} 31^{\prime \prime} \mathrm{E}\right)$ (Figure 1). All streams are surrounded by boreal forest, have a stream width of about 2-5 meters, and stream bottoms that are dominated by hard substrate consisting of a mixture of sand, gravel, cobble and boulder. Stream order (a measure of stream size and nutrient flow, Strahler 1957) varied between 1 and 2. First order streams (1) are the outermost tributaries, which join together to form a second order stream 2, and so on. The new sites were chosen based on their similarity to the former study sites in environmental variables, and because they had overwintering Dippers. Information on overwintering Dippers were obtained from local birders and the Swedish Species Observation System for bird reports. The Species Observation System is a web-based platform where the public can report sightings of Swedish plants, animals, and fungi (http://www.artportalen.se).

The streams were visited once each week from approximately October 15, which is before the first Dippers arrived, to April 15 which is after the last Dippers had left. The presence or absence of birds was determined by walking along the streams at a stretch of about 400-500 m. If birds were observed during this initial walk, we always put up mistnets and tried to capture the Dippers, independent of whether they were previously banded or not. If no birds were observed during the initial walks, no mistnets were used. This gave us information on arrival and departure of the banded birds. Information from local birders, and records in the Swedish Species Observation System for bird reports, indicated no presence of Dippers outside the period of our visits to the streams, and accordingly, no evidence of breeding, in any of the studied streams during the 1975-1979 and 2010-2014 periods. In the province of Västerbotten there were only five reported records in total of Dippers outside the study period. Indeed, very few indications of suspected breeding (and no con- firmed) have been reported within a radius of $50 \mathrm{~km}$ of the study area (Olsson \& Wiklund 1999, Swedish Species Observation System for bird reports). Depending on the stream and the ice situation, Dippers were only captured along a $100-400 \mathrm{~m}$ section of the 400-500 m distance initially walked to confirm presence or absence of birds at each site. Once a bird was captured, the date was noted, and sex and age was determined as in Lundberg et al. (1981). No birds with a wing length of 92-95 $\mathrm{mm}$ were caught (males $>94 \mathrm{~mm}$ and females $<94 \mathrm{~mm}$; Svensson 1975). We therefore feel certain that our sex determination is correct. Since neither Lundberg et al. (1981) nor we visited the streams on a daily basis the earliest and last sighting by a bird could differ at a maximum of 7 days from the true arrival and departure day. As in Lundberg et al. (1981) the results are based only on birds caught and identified through mistnet captures.

We also calculated average monthly temperature (December, January, and February) based on data from Umeå airport weather station for 1966-1980 and 2001-2014 (SMHI 2015b). This weather station is situated within the $39 \mathrm{~km}$ radius of the study sites. The chosen periods also included 10 years prior to each study period, because we assumed that birds do not adapt instantaneously to changes in winter temperature.

\section{Statistical analysis}

Raw data on birds banded in 1975-1979 was available from The Swedish Museum of Natural History. However, that data did not show the recaptures at the local level. Hence, it could not be used for our purpose because it did not show the length of the stay of each individual at a yearly basis. Instead, we examined possible differences between time periods by comparing mean values and $95 \%$ confidence intervals provided by Lundberg et al. (1981) with the averages and confidence intervals estimated in our study. If the confidence intervals between the two time periods overlapped for the variables in focus we determined the comparison between the time periods as non-significant. Mean and confidence interval from the variables in Lundberg et al. (1981) were obtained graphically by scanning the figures from their article, and then using the program Image $\mathrm{J}$ (Abramoff et al. 2004) to estimate the mean and error bars from each of their figures. The program allows to measure values directly from the figures, since a measurement scale, which is used as a reference scale, can be drawn along the axes in the scanned figures. When error bars were given as standard errors (SE) in Lundberg et al. (1981), we recalculated 
the SE to $95 \%$ confidence intervals by multiplying the SE by 1.96. For the 2010-2014 data sets, we had the raw data and calculated mean values and 95\% confidence intervals in Microsoft Excel (Microsoft 2007). We merged data from all three streams before calculating the monthly means per year for the period 2010-2014 (as in Lundberg et al. 1981) for this later period.

Three variables were compared between the two study periods. 1) Numbers of overwintering birds were compared by comparing the percentage of birds each month estimated from the total number of birds for the entire winter. Total number of birds was estimated from the numbers banded. We first calculated the percentage of birds caught each month for each year and then the average and 95\% confidence interval for the period using year as replicates. 2) The percent of adult birds per month was estimated by first calculating the percentage for each month and year and thereafter retrieving a mean value and 95\% confidence interval for each month averaged over the whole time period. 3) Sex ratio was calculated in the same way using percentage of males as the variable instead of percentage of adults. In summary, we could only compare the periods quantitatively using mean and $95 \%$ confidence intervals, and some caution must therefore be taken when interpreting the results. The comparison was done with the actual numbers retrieved or calculated, but we present figures showing mean and $95 \%$ confidence intervals.

\section{Results}

\section{Number of overwintering birds and temperature increase}

Lundberg et al. (1981) captured and banded 63 Dippers in the three main streams (Ängerån, Kvarnfors, and Norsån) in 1975-1979. In 2010-2014, we captured 43 Dippers in Djupsundsbäcken, Kvarnfors, and Bubäcken. In total 21 of these 43 Dippers were recaptured within the winter season of ringing, on in total 44 occasions. The total number of trapping occasions (new ringing plus recaptures over the five years was 30 , but the number of visits to the streams was considerable larger. Site fidelity of the Dippers to a specific stream was high within in the years 2010-2014, with banded Dippers only being recaptured in the stream where they initially where captured and banded. High site fidelity was also reported by Lundberg et al. (1981). The average temperature increase between the two study periods was about $2^{\circ} \mathrm{C}$ (Table 1 ).

In 2010-2014, a significantly greater proportion
Table 1. Average monthly temperature $\left({ }^{\circ} \mathrm{C}\right)$ at Umeå airport for 1966-1980 and 2000-2014, and increase in average monthly temperature between the two periods.

Medeltemperatur vid Umeå flygplats för åren 1966-1988 och 2000-2014, samt ökningen i medeltemperatur mellan dessa tidsperioder.

\begin{tabular}{llll}
\hline Years/month & December & January & February \\
\hline $1966-1980$ & -5.7 & -9.1 & -9.7 \\
2000-2014 & -3.9 & -6.5 & -7.2 \\
Temperature increase & 1.8 & 2.6 & 2.5 \\
\hline
\end{tabular}

of birds had already arrived in October and November as compared to 1975-1979 (Figure 2; no overlap of $95 \%$ confidence intervals). No birds were present in the area during October 1975-1979, but four birds were present in October 2010-2014. For the period from December to March, the 95\% confidence intervals overlap, suggesting no difference between the two periods in proportion of birds present each month. No Dippers were in their wintering areas in April during 2010-2014, but $\sim 8 \%$ of the birds were still in wintering areas in April 1975-1979 (Figure 2). The earliest arrivals and latest departures were 3 November and 23 April, in 1975-1979, and 19 October and 28 March in 2010-2014. These data suggest that, since 1979, Dippers have started arriving in wintering areas two weeks earlier and leaving more than three weeks earlier. Since we visited the streams once a week the exact advance of arrival and departure date might differ by a maximum of 7 days. Even with these 7 days of uncertainty included there is still a shift of 1-2 weeks in arrival and departure time.

\section{Percent adult birds and sex ratio}

Juvenile birds seem to arrive to the overwintering area before the adults, and this was evident under both study periods (Figure 3). Confidence intervals of percent adult birds overlapped considerably between the two time periods and no significant difference was evident for any of the months (Figure 3). The 95\% confidence intervals for sex ratios for each month during the two time periods overlapped considerably, and hence no significant difference was evident for any of the months (Figure 4).

\section{Discussion}

We found support for the predicted shift in the migratory behaviour of Dippers in the areas studied. On average in 2010-2014, the first individual Dippers arrived two weeks earlier and left three weeks earlier 


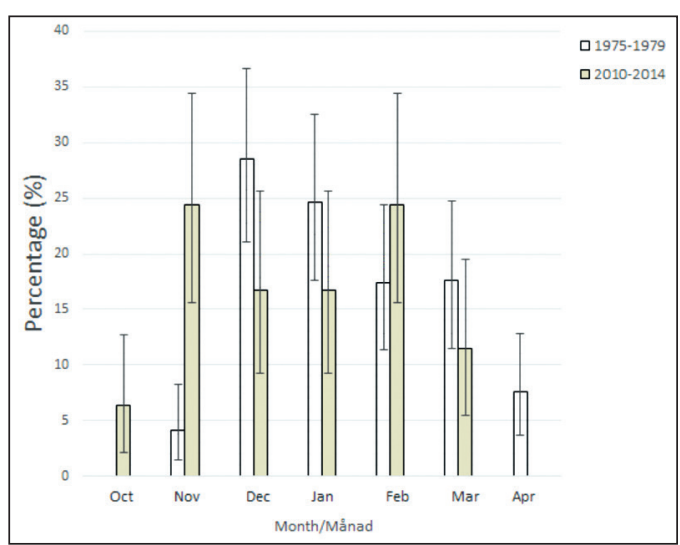

Figure 2. Percent White-throated Dippers in each month relative to total number of birds for each year for the time periods 1975-1979 and from 2010-2014. Error bars denote 95\% confidence intervals.

Procent strömstarar för varje undersökningsmånad relativt det totala antalet strömstarar för tidsperioderna 1975-1979 och 2010-2014. Felstaplar motsvarar $95 \%$ konfidensintervall.

compared to 1975-1979. Similarly, in 2010-2014, a larger proportion of the Dippers arrived in the area already in October-November and fewer were present in April, compared to 1975-1979. Since we, as in Lundberg et al. (1981), did not analyse how long each individual bird stayed during the winter, our data show only when the first birds arrived and the last ones departed. It does not show how long each individual bird stayed. Shifts in migration behaviour of birds have been suggested to be an effect of global warming and have been commonly observed for spring migration. For example, an earlier spring arrival time of short distance migrating birds that migrate to Scandinavia from continental Europe has been observed (Hüppop \& Hüppop 2003). This earlier arrival is correlated with global warming factors such as spring temperature and North Atlantic Oscillation index (Hüppop \& Hüppop 2003). Similarly, Cotton (2003) found that arrival and departure times for long distance migrants in the United Kingdom had advanced eight days and these changes were associated with higher winter temperatures in subSaharan Africa and higher summer temperature in the United Kingdom. Few studies are available that show changes in arrival and departure time at overwintering grounds. Nevertheless, in a review on waterbirds, Guillemain et al. (2013) showed an advancement of departure time over the last decades from their wintering grounds. Our study shows that arrival date and departure date at wintering areas of one passerine species that overwinter in a seasonal climate zone has shifted in phenology over a 40 -year period in an area were temperature has increased about $2^{\circ} \mathrm{C}$ during the overwintering period.

What Lundberg et al. (1981) found suggested a change in overall sex and age ratio over season with more adults and males later on during the overwintering season. We found no differences in age or sex ratio between the two study periods, since the $95 \%$ confidence intervals overlapped between study periods for each month, suggesting that the within-season pattern was the same in the two study periods. In many bird species, sex ratio differences at geographically different overwintering grounds have been explained by dominance status, where in most cases assumed dominant males overwinter closer to the breeding ground and thereby cause differences in sex ratio at overwintering ground (Prescott \& Middleton 1990, Marra 2000). We feel that our data set is too small to allow discussion about sex ratio at our study site, but see Lundberg et al. (1981). However, using a much larger data set Andersson \& Wester (1973) found a significantly higher proportion of overwintering females and juveniles at a study site in southern Sweden. Lundberg et al. (1981) speculated that the differences in sex and age ratio between studies could be due to dominance status where dominant individuals (males and adults, Bryant \& Newton 1996) over winter closer to the breeding grounds which in our case is northwestern Norway (Cramp 1988, Fransson \& Hall-Karlsson 2008). In general, differences in age ratio at autumn arrival seems to depend on whether the birds moult at their breeding or overwintering sites. If adults moult at their overwintering grounds they usually leave the breeding grounds before the juveniles (Newton 2011). The Dipper moults at their breeding grounds (Svensson 1975), and hence we expect juveniles to arrive first to the wintering grounds, which seems to be the case in both study periods.

Using the earliest day of arrival for the 2010-2014 period and comparing that with the earliest arrival of the period 1975-1979 generates a mean shift of 0.42 days earlier arrival per year. This figure is somewhat higher compared to other migration shift observed over similar time periods. Tøttrup et al. (2006) found an earlier arrival in spring averaging 0.26 days/year in Scandinavian passerines over a 20 -year period, and Cotton (2003) found a mean of 0.27 days earlier spring arrival per year for migratory birds over a 30-years period in the United Kingdom. Unfortunately, the departure dates in autumn have not been studied to the same extent. Nevertheless, Jenni \& Kéry (2003) found that short distance migrants had delayed their autumn migration by 0.11 days/year while long distance migrants had advanced their au- 


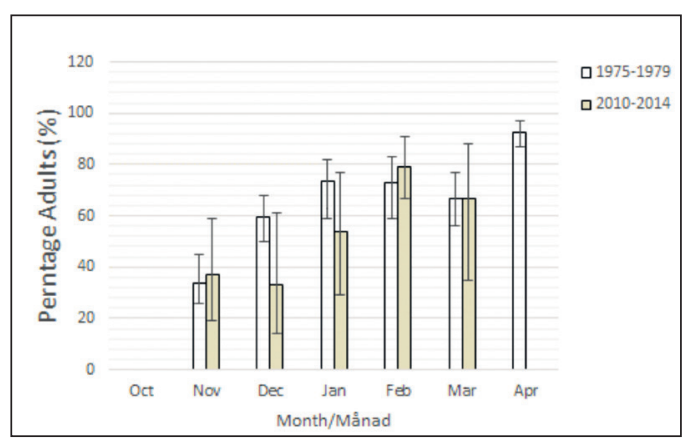

Figure 3. Percent of adult White-throated Dippers in the overwintering streams relative to total number of juveniles and adults present. Error bars denote $95 \%$ confidence intervals.

Procent adulta strömstarar relativt det totala antalet som övervintrar $i$ de studerade vattendragen. Felstaplar motsvarar $95 \%$ konfidensintervall.

tumn migration by 0.08 days/year during a 30 -years period. Dippers are short distance migrants according to the definition of migration distances studied in Jenni \& Kéry (2003), but the change in autumn migration we found in our study is opposite to that found in Jenni \& Kéry (2003) for short distance migrants. Jenni \& Kéry (2003) studied autumn passage dates rather that arrival at wintering grounds, which may explain the difference. Alternatively, Dippers have not reacted to climate warming in the same way as most other short-distance migrants.

Being short-distance migrants, Dippers may be efficient at tracking temperature variation among years and therefore there has been a fast change to the alteration in temperature. In fact, Hegelbach (2001) found that the onset of breeding by Dippers was correlated with air temperature in Switzerland and hence arrival and departure time at overwintering might consequently also be correlated with temperature at breeding grounds. A similar pattern has been found in other passerines with regard to wintering area temperature and spring arrival (Gordo et al. 2005). The Dippers in our study area probably breed west/northwest of their wintering area, i.e. in the Swedish and Norwegian mountains, because Dippers in northern Europe have east/south east migration routes to their winter grounds (Cramp 1988, Fransson \& Hall-Karlsson 2008). It would therefore be interesting to study temperature changes at the breeding grounds for the birds that overwinter in our study area.

\section{Acknowledgements}

We thank William Jones for comments on a previous version of the article. This work was supported by a grant from the Elis Wides foundations.

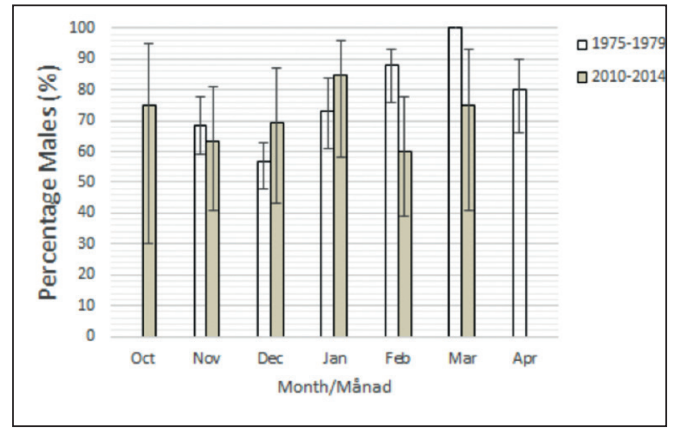

Figure 4. Percent of male White-throated Dippers in the overwintering streams relative to total number of males and females present. Error bars denote $95 \%$ confidence intervals. Procent hanar av strömstarar relativt det totala antalet hanar som övervintrar $i$ de studerade vattendragen. Felstaplar motsvarar $95 \%$ konfidensintervall.

\section{References}

Abramoff, M. D., Magalhaes, P. J. \& Ram. S. J. 2004. Image Processing with ImageJ. Biophot. Intern. 11: 36-42.

Andersson, S. \& Wester, S. 1976. Sex and age ratios of wintering Dippers Cinclus c. cinclus (L.). Ornis Scand. 4: 153-156.

Andersson, S. \& Wester, S. 1976. Long distance recoveries of Dippers Cinclus c. cinclus in Denmark, Finland, Norway and Sweden. Vår fågelvärld 35: 279-286. (In Swedish)

Bryant, D.M. \& Newton, A.V. 1996. Dominance and survival of dippers Cinclus cinclus. Beh. Ecol. Sociobiol. 38: 173-181.

Cotton, P. A. 2003. Avian migration phenology and global climate change. Proc. Natl. Acad. Sci. USA. 100: 12219 12222.

Cramp, S. (ed.) 1988. The Birds of the Western Paleartic, Vol. $V$. Oxford University Press, Oxford, UK.

Fransson, T. S, \& Hall-Karlsson, S. 2008. Svensk ringmärkningsatlas (Swedish bird ringing atlas), vol 3. Stockholm, Sweden. SOF Förlag (in Swedish)

Gordo, O., Brotons, L., Ferrer, X. \& Comas, P. 2005. Do changes in climate patterns in wintering areas affect the timing of the spring arrival of trans-Saharan migrant birds? Global Change Biol. 11: 12-21.

Guillemain, M., Pöysä, H., Fox, A. D., Arzel, C., Dessborn, L., Ekroos, J., Gunnarsson, G., Holm, T.E., Christensen, T.K., Lehikoinen, A., Mitchell, C., Rintala, J. \& Møller, A.P. 2013. Effects of climate change on European ducks: what do we know and what do we need to know? Wildlife Biol. 19: 404-419.

Hegelbach, J. 2001. Wassertemperatur und Blütenphänologie als Anzeiger des früheren Brutbeginns der Wasseramsel (Cinclus cinclus) im schweizerischen Mittelland. $J$. Ornithol. 142: 284-294.

Hüppop, O., \& Hüppop, K. 2003. North Atlantic Oscillation and timing of spring migration in birds. Proc. R. Soc. B 270: 233-240.

Jenni, L. \& Kéry, M. 2003. Timing of autumn bird migration under climate change: advances in long-distance migrants, delays in short distance migrants. Proc. R. Soc. B 270: 1467-1471. 
Jonzén, N., Lindén, A., Ergon, T., Knudsen, E., Vik, J. O., Rubolini, D., Piacentini, D. \& Brinch, C. 2006. Rapid advance of spring arrival dates in long-distance migratory birds. Science 312: 1959-1961.

Lehikoinen, E. \& Hakala, J. 1988. Variation in weight of migratory Dippers Cinclus cinclus in their Finnish winter quarters. Bird Study 35: 101-108.

Lundberg, P., Bergman, A. \& Olsson, H. 1981. On the ecology of wintering Dippers (Cinclus cinclus) in northern Sweden. J. Ornithol. 122: 163-172.

Marra, P. P. 2000. The role of behavioral dominance in structuring patterns of habitat occupancy in a migrant bird during the nonbreeding season. Behav. Ecol. 11:299-308.

Microsoft. 2007. Microsoft Excel. Microsoft, Redmond, WA.

Møller, A. P., Fiedler, W. \& Berthold, P. (eds.). 2011. Effects of climate change in birds. Oxford University Press, UK, 344 pp.

Musilova, Z., Musil, P., Zouhar, J. \& Romportl, D. 2015. Long-term trends, total numbers and species richness of increasing waterbird populations at sites on the edge of their winter range: cold-weather refuge sites are more important than protected sites. J. Ornithol. 156: 923-932.

Newton I. 2011. Migration within the annual cycle: species, sex and age differences. J. Ornithol. 152:169-185.

Prescott, D. R. \& Middleton, A. L. 1990. Age and sex differences in winter distribution of American Goldfinches in eastern North America. Ornis Scand. 21:99-104.

Olsson, C. \& Wiklund, J. 1999. Västerbottens Fåglar. Västerbottens Ornitologiska Förening, Umeå. 656 pp. (in Swedish).

SMHI [online]. 2015a. Sveriges klimat har blivit varmare och blötare. <http://www.smhi.se/kunskapsbanken/klimat/ sveriges-klimat-har-blivit-varmare-och-blotare-1.21614>.

SMHI [online]. 2015b. Observationsdata och stationsinformation https:/www.smhi.se/klimatdata/meteorologi/ temperatur

Strahler A. N. 1957. Quantitative Analysis of Watershed Geomorphology. Trans. Am. Geophys. Union. 38: 913-920.

Svensson, L. 1975. Identification guide to European passerines. Naturhistoriska Riksmuseet, Stockholm.

Thorup, K., Tøttrup, A. P. \& Rahbek C. 2007. Patterns of phenological changes in migratory birds. Oecologia 151: 697-703.

Tøttrup, A. P., Thorup, K. \& Rahbek, C. 2006. Patterns of change in timing of spring migration in North European songbird populations. J. Avian Biol. 37: 84-92.
Van Buskirk, J., Mulvihill, R. S., \& Leberman, R. C. 2009. Variable shifts in spring and autumn migration phenology in North American songbirds associated with climate change. Global Change Biol 15: 760-771.

Vuorinen, J. \& Tyrberg, T. 1994. Strömstarens teoretiska vårflyttningskapacitet. Cincluc Scandinavicus 7: 4-9. (in Swedish).

\section{Sammanfattning}

Under de senaste 100 åren har jordens temperatur ökat med ca 0.7 grader. Förändringar av temperaturen påverkar växters och djurs ekologi. Till exempel så har fåglars flyttningsvanor förändrats. Många arter anländer och lämnar sina häckningsområden på norra halvklotet tidigare än för några decennier sedan. I denna studie undersökte vi fenologin hos strömstarar som övervintrar i Västerbotten. Vi jämför ankomst- och avfärdsdatum samt åders- och könskvot under åren 2010-2014 med data från en studie som gjordes 1975-1979. Data för båda perioderna samlades in med hjälp av slöjnätsfångst (fångst/återfångst) i fem stycken mindre vattendrag. En jämförelse av medeltemperaturen mellan de två studieperioder visade att medeltemperaturen ökat med ca $2{ }^{\circ} \mathrm{C}$ i studieområdet. Under perioden 1975-1979 kom de första strömstararna till övervintringsområdet i november och de sista strömstararna lämnade området under april månad. Under perioden 2010-2014 däremot, kom de första strömstararna till övervintringsområdet $\mathrm{i}$ oktober och inga strömstarar fanns kvar i april. Våra resultat visar att strömstararna anlände till övervintringsområdet i medeltal två veckor tidigare och lämnade området tre veckor tidigare under 2010-2014 jämfört med för 35 år sedan (1975-1979). Juvenila fåglar anlände före adulta fåglar under båda tidsperioderna. Vi hittade inga skillnader i ålder- och könskvot mellan de både studieperioderna. 